Ann. Biol. anim. Bioch. Biophys., 1978, 18 (2 B), 391-398.

\title{
Meiotic effects in chromosomally derived male sterility of mice
}

\author{
by A. G. SEARLE, C. V. BEECHEY, E. P. EVANS * \\ MRC Radiobiology Unit., Harwell, Oxon, OX11 ORD \\ *Sir William Dunn School of Pathology, Oxford., U. K.
}

\begin{abstract}
Summary. Much sterility in male (though not in female) mice can be related to the presence of specific types of chromosome anomaly. These include the $X X Y$ and XYY conditions, failures of association of $X$ and $Y$, heterozygosity for reciprocal translocations involving the $X$ or $Y$ chromosomes as well as some which involve autosomes only, tertiary frisomic derivatives of these and certain multiple Robertsonian translocations. In all of these the sterility stems from a defect of spermatogenesis, which leads to the production of few or no spermatozoa. Studies of reciprocal translocations are of particular value for elucidating the mechanisms involved becausa different ones exhibit an almost complete range of effects, from those with normal sperm production to those in which spermatogenes is stops at the onset of meiosis. Between these extremes a number of characteristic patterns can be discerned but in general the cessation of spermatogenesis tends to be graded rather than abrupt. The effects on spermatogenesis are associated with special characteristics of the translocations themselves, namely a tendency for one point of exchange to be close to (or even within) centromeric heferochromatin and the other fairly distal on the chromosomes involved. This frequently leads to the formation of long and short marker chromosomes and to the production of viable tertiary trisomic mice, which are also male-sterile as a rule.
\end{abstract}

Mammalian spermatogenesis is a complex process, which is influenced by a large number of both intrinsic and extrinsic factors. Only in recent years has it been realised to what extent the intrinsic control depends on the normal arrangement of the genome. Chromosome anomalies which have no other discernible effects in the individuals carrying them may nevertheless completely disrupt the process of spermatogenic maturation in the male. In this respect, the immature male germ-cell differs markedly from the immature female one, which seems little affected by chromosome anomalies. It also differs from the mature spermatozoon, which is capable of fertilization even when it carries gross chromosomal anomalies which would be lethal in a zygote.

Table 1 illustrates the range of chromosome anomalies which affect spermatogenesis in the mouse and shows that some of these act at a certain stage while others are less specific. The $X X Y$ and $X Y Y$ conditions are very rare in mice. $X X Y$ mice appear to have no germ-cells, though Sertoli cells remain (Ford ef al., 1975). The same seems true of human $X X Y$ individuals, in which the spermatogenic activity described in some reports may be connected with $X Y / X X Y$ mosaicism (Chandley, 
1975). The $X Y Y$ condition is associated with post-meiotic spermatogenic breakdown, but with some formation of spermatids and spermatozoa. Although sterility is usually complete, a male XYY mouse which was fertile when young has been reported (Evans, Beechey and Burtenshaw, 1978). XYY men are frequently fertile, although some attend clinics for the sub-fertile and are then frequently found to have spermatogenic impairment, which may be severe (Chandley, 1975). In X-Y dissociation at metaphase I, which is also found in both man (Chandley et al., 1976) and mouse (Beechey, 1973) there appears to be a single critical stage of spermatogenic arrest : at the first meiotic division, so that few or no secondary spermatocytes are formed. Possibly related to this is the spontaneous univalence described by Purnell (1973) in a single male mouse with small testes in which very few spermatozoa were found. An average of only 7 bivalents per spermatocyte were found at metaphase $I$, although $X$ and $Y$ chromosomes were occasionally paired. Pearson et al. (1970) have described a similar condition in man.

TABLE 1

Some chromosomal anomalies which affect fertility in male mice

\begin{tabular}{|c|c|c|}
\hline Type of anomaly & Nature of effect & References \\
\hline$X X Y$ & No spermatogenic cells & $\begin{array}{l}\text { Cattanach (1961), Slizynski } \\
\text { (1964), Ford ef al. (1975) }\end{array}$ \\
\hline$X-Y$ separation & $\begin{array}{l}\text { Variable degree of spermatogenic im- } \\
\text { pairment, but some spermatids and } \\
\text { spermatozoa usually formed } \\
\text { No secondary spermatocytes }\end{array}$ & $\begin{array}{l}\text { Cattanach and Pollard (1969), } \\
\text { Rathenburg and Muller (1973), } \\
\text { Evans ef al. (1977) } \\
\text { Beechey (1973), Chandley ef } \\
\text { al. (1976) }\end{array}$ \\
\hline $\begin{array}{l}\text { X-autosome transloca- } \\
\text { tions }\end{array}$ & $\begin{array}{l}\text { Usual pachytene arrest but } \mathrm{T} 16 \mathrm{H} \\
\text { continues to metaphase I and II }\end{array}$ & $\begin{array}{l}\text { Lyon ef al. (1964), Russell and } \\
\text { Montgomery (1969), Eicher } \\
\text { (1970) }\end{array}$ \\
\hline $\begin{array}{l}\text { Y-autosome transloca- } \\
\text { tions }\end{array}$ & Spermiogenic impairment & $\begin{array}{l}\text { Léonard and Deknudt (1969), } \\
\text { Cacheiro et al. (1974) }\end{array}$ \\
\hline $\begin{array}{l}\text { Autosome-autosome } \\
\text { translocations (some) }\end{array}$ & $\begin{array}{l}\text { Variable degree of spermatogenic im- } \\
\text { pairment }\end{array}$ & $\begin{array}{l}\text { Lyon and Meredith (1966), } \\
\text { Cacheiro ef al. (1974), Searle } \\
\text { (1974) }\end{array}$ \\
\hline $\begin{array}{l}\text { Tertiary trisomies derived } \\
\text { from autosome-auto- } \\
\text { some translocations }\end{array}$ & As above & As above \\
\hline $\begin{array}{l}\text { Common arms in trans- } \\
\text { locations } \\
\text { Multiple univalents }\end{array}$ & $\begin{array}{l}\text { Variable degree of spermatogenic im- } \\
\text { pairment ; some fertile } \\
\text { Spermiogenic impairment }\end{array}$ & $\begin{array}{l}\text { Carter ef al. (1956), Evans (1976) } \\
\text { Winking and Gropp (1977) } \\
\text { Purnell (1973) }\end{array}$ \\
\hline
\end{tabular}

Translocations involving the $X$ or $Y$ chromosomes are well known to cause sterility in male mice, the effect on spermatogenesis tending to be more severe in those involving the $X$-chromosome. Combinations of translocations with a common chromosome also tend to be male-sterile (Carter, Lyon and Phillips, 1956) and may even be lethal when each involves the same two chromosomes (Beechey and Searle, 1975). Double heterozygotes for Robertsonian translocations with a common arm are often male-sterile (Evans, 1976), as in four different combinations involving chr 8 
(Winking and Gropp, 1977). Spermatozoa are greatly reduced in number or are completely absent, while one example studied in detail revealed a breakdown in spermatid maturation setting in at stage IX-3 (Döring. Winking and Gropp, 1975). However, some combinations of the kind described are fully fertile while others are intermediate, i.e. with lowered fertility (Evans, 1976).

Double heterozygotes for reciprocal translocations may also be male-sterile (Carter, Lyon and Phillips, 1956) even when neither of the single heterozygotes are so. As Evans (1976) has pointed out, these double reciprocal or Robertsonian translocations commonly form long chain multivalent configurations at meiosis. It is interesting to note that the formation of chain multivalents, rather than rings, is also a very characteristic feature of male-sterile reciprocal translocations involving the autosomes, as discussed below.

Lyon and Meredith (1966) were the first to show that certain translocations which did not involve the sex-chromosomes nevertheless caused sterility of the male heterozygote because of spermatogenic impairment. They also noted that the translocations tended to give a high proportion of chain configurations at meiotic metaphase $I$, in contrast to the usual preponderance of rings. Further work has amply confirmed this tendency (Cacheiro, Russell and Swartout, 1974 ; Searle, 1974).

We have generated a number of translocations of this type, as well as $X$-autosome translocations, in an experiment in which male mice were given doses of 0-1200 rad

TABLE 2

Spermatogenic anomalies and testis weights in heterozygotes for male-sterile translocations $(T)$ and tertiary trisomics (Ts). $\mathrm{Ml}=$ metaphase-I

\begin{tabular}{|c|c|c|}
\hline Translocation & Anomalies & $\begin{array}{c}\text { Testis weight } \\
\text { (p. } 100 \text { of normal) }\end{array}$ \\
\hline $\mathrm{T}(5 ; 12) 31 \mathrm{H}$ & Reduced numbers of spermatozoa & 58 \\
\hline Ts $31 \mathrm{H}^{*}$ & $\begin{array}{l}\text { Few spermatids, practically no } \\
\text { sperm }\end{array}$ & 31 \\
\hline$T(6 ; 12) 32 \mathrm{H}$ & $\begin{array}{l}\text { Few sperm, spermatids also redu- } \\
\text { ced }\end{array}$ & 53 \\
\hline $\mathrm{T}(4 ; 8) 36 \mathrm{H}$ & $\begin{array}{l}\text { Many Ml spermatocytes but few } \\
\text { later stages }\end{array}$ & 44 \\
\hline$T(X ; 11) 38 \mathrm{H}$ & $\begin{array}{l}\text { Primary spermatocytes, not reach- } \\
\text { ching MI }\end{array}$ & 34 \\
\hline Ts $38 \mathrm{H}^{*}$ & MI reached but no sperm & $?$ \\
\hline $\mathrm{T}(\mathrm{X} ; 4) 37 \mathrm{H}$ & $\begin{array}{l}\text { Spermatocytes mainly stop at pa- } \\
\text { chytene but a few reach MI }\end{array}$ & 32 \\
\hline$T(16 ; 17) 43 \mathrm{H}$ & Very few post-meiotic stages & 32 \\
\hline $\mathrm{T}(1 ; 7) 40 \mathrm{H}$ & $\begin{array}{l}\text { Spermatogonia and early sperma- } \\
\text { tocytes only }\end{array}$ & 27 \\
\hline$T(11 ; 19) 42 \mathrm{H}$ & $\begin{array}{l}\text { Primary spermatocytes reach pa- } \\
\text { chytene only }\end{array}$ & 26 \\
\hline
\end{tabular}

* With the normal balanced chromosome set (20 II) plus the small translocation product. 
acute X-irradiation (Searle ef al., 1974). Daughters were tested for semi-sterility and were bred from if they produced sterile sons. Another male-sterile translocation $(\mathrm{T} 31 \mathrm{H})$ in the present series was induced by irradiation of female mice (Searle and Beechey, 1974). Table 2 lisis these translocations, as well as two tertiary trisomic conditions derived from them which were also male-sterile, and gives approximate testis weights, mainly based on measurements at 6-8 weeks of age, as percentages of normal. Information on the chromosomes involved (placed in parentheses within the translocation name) was obtained by the ASG and trypsin banding methods, with Giemsa staining.

Table 2 shows that in general there was quite a good correlation between testis weight reduction and the severity of spermatogenic effects, which ranged from a reduced sperm-count in $\mathrm{T} 31 \mathrm{H}$ to the presence of only the earliest meiotic stages in $\mathrm{T} 40 \mathrm{H}$ and $\mathrm{T} 42 \mathrm{H}$. Detailed quantitative studies of the spermatogenic population in seminiferous fubules have not yet been made, but examination of air-dried preparations made from suspensions of germ-cell (Evans, Breckon and Ford, 1964) as well as histological sections of whole testes made it clear that the effect tended to be graded rather than abrupt, with some germ-cells surmounting a particular critical stage but failing to pass the next one. Thus in T37H most spermatocytes failed to progress further than pachytene, but a few managed to reach metaphase I. There seemed to be critical stages at pachytene, around meiotic metaphase 1 and during sperm formation, but more work is needed to confirm observations. Cacheiro, Russell and Swartout (1974) reported that in their series of $\mathbf{4 2}$ sterile males resulting from post-meiotic treatment with mutagens, 15 showed a spermatogenic block in pachytene and 9 at diakinesis, while 17 had some mature spermatids. One lacked spermatogenic cells altogether, but seemed to be chromosomally normal. In our series, there were few signs of any spermatogenic wave in seminiferous tubules from heterozygotes for translocations with the greatest effect, but there was heterogeneity with respect to severity of effect between different segments of tubule. Some sections of tubule looked remarkably emply, with considerable depletion in the numbers of early spermatocyte stages. Large darkly-staining cells were found in the lumen of tubules and sometimes these looked multinucleate. In general, there was no marked difference between the balanced translocation carriers and the tertiary trisomics in the types of effect seen, but there was a difference in the severity of effect.

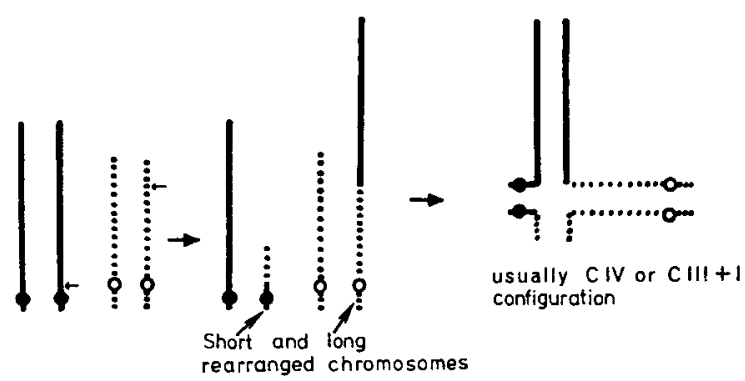

FIG. 1. - Generation and pochytene configuration of typical male-sferile translocation, with positions of break-points marked with small arrows. 
The preponderant formation by these male-sterile translocation heterozygotes of chain configurations (CIV or CIII $+I$ ) at metaphase 1 (if this is reached) results from failure of chiasma formation in one arm or in adjacent arms of the translocation cross (fig. 1). This is associated with formation of particularly long and/or short translocation products, i.e. somatic marker chromosomes like the well-known T6 marker which is itself male-sterile on cerfain genetic backgrounds (Baranov and Dyban, 1968). Six out of the eight male-sterile translocations described here were somatic markers of this type. Of the remaining two, T36H included a submetacentric marker, while $\mathrm{T} 43 \mathrm{H}$ had a break-point close to the centromere of $\mathrm{Chr} 16$, with translocation of $\mathrm{C}$ band material (centromeric heterochromatin) to $\mathrm{Chr} 17$, thus generating a marker chromosome in C-banded preparations. As figure 1 shows, the characteristics of these translocations are those expected if one break-point is near the centromere and the other fairly distal on the chromosome (Searle, 1974). Figure 2 gives the approximate break-point positions for the Harwell series of male-sterile translocations to show that this is indeed the case. Since at meiotic metaphase in female carriers the short translocation marker may frequently segregate independently because of failure of chiasma formation, this type of translocation is likely to generate tertiary trisomic and monosomic zygotes, which may be viable because of the relatively small amount of chromosomal material which is duplicated or deficient.

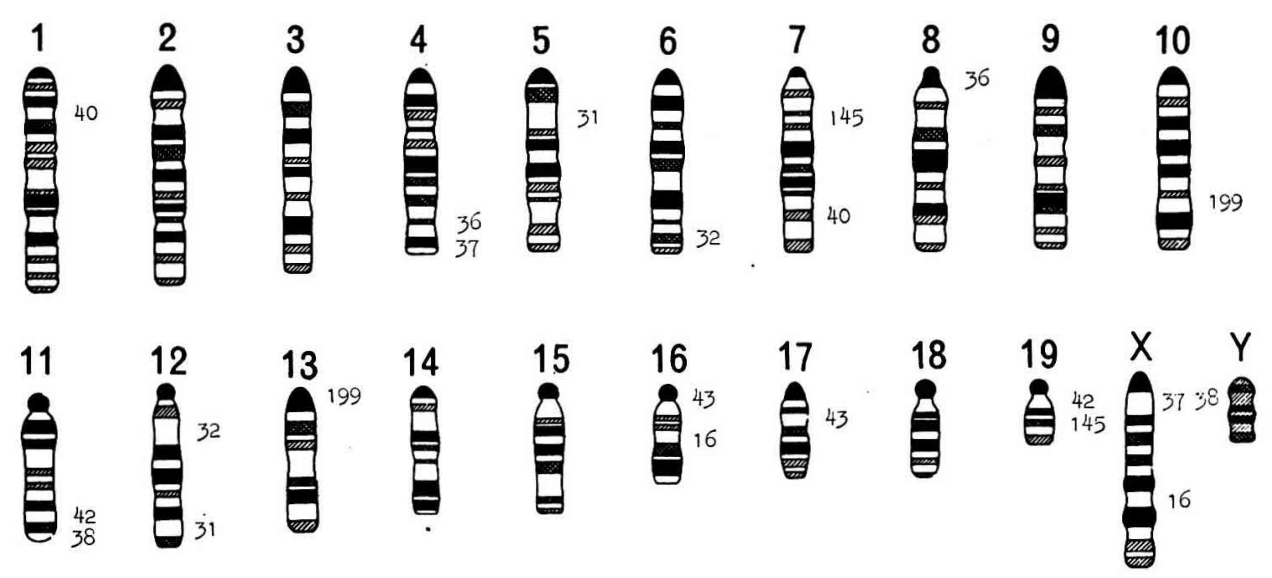

FIG. 2. - Approximate positions of break-points in Harwell series of male-sterile translocations, in relation to the chromosome banding patiern in the mouse (Nesbift and Francke, 1973). For further details refer to Beechey ef al., $1976(\mathrm{~T} 31 \mathrm{H})$; Dev ef ol., $1974(\mathrm{T1} 199 \mathrm{H})$; Eicher and Washburn, 1977 ( $T 16 \mathrm{H}$ and $T 145 H$ ) ; Evans, Beechey and Searle, 1977 (others).

There can be little doubt these translocations act autonomously on the germ-cells carrying them, even though they may have systemic effects of which we are not yet aware. In males, this type of translocation has only been recovered from post-meiotic irradiation, in which the treated germ-cell does not divide further before forming the zygote. Presumably, these translocations are not recovered after spermatogonial irradiation because the germ-cells carrying them are eliminated during subsequent spermatogenesis, as a result of autonomous action. This phenomenon also helps to 
explain the reduced transmission of reciprocal translocations induced by spermatogonial irradiation (Ford ef al., 1969).

In seeking an explanation for the effects of these translocations on spermatogenesis we should probably look at events very early in meiosis, since this seems to be the stage at which germ-cell depletion is first manifest in those most severely affected. The tendency for one breakpoint to be close to the centromere suggested to Cacheiro, Russell and Swartout (1974) that the sterility resulted from position-effect inactivations, while Searle (1974) thought that disturbances to spermatocyte formation might be expected when homologous $C$-bands are attached to synaptonemal complexes of very different lengths, because this might interfere with attachments to the nuclear membrane. Moses, Russell and Cacheiro (1977) have studied synaptonemal complexes in two male-sterile $X$-autosome translocations and found a disturbance of $X-Y$ synapsis in one, in which the breakpoint was in the pairing region of the $X$. One other interesting finding which may throw further light on the nature of the basic disorder is that of Forejt (1974, 1977), that there is an abnormally high frequency of C-band contact between the $X$ chromosome and the translocation configuration in a number of translocations affecting male fertility. However, much more work will be needed before it becomes clear to what extent the wide range of chromosome anomalies affecting meiotic stages of spermatogenesis share a common link in their causation.

$27^{e}$ Congrès international des Sciences physiologiques, Symposium " Germ and somatic cell interaction " Paris, 21-23 juillet 1977.

Acknowledgments. - We are very grateful to Dr. C. E. Ford FRS for his comments.

Résumé. Beaucoup de cas de stérilité mâle (mais non femelle) peuvent être rattachés chez la Souris à la présence d'anomalies chromosomiques spécifiques, parmi lesquelles les situations $X X X, X Y Y$, les défauts d'association entre $X$ et $Y$, les hétérozygotes pour les translocations réciproques impliquant les chromosomes $X$ ef $Y$ aussi bien que quelques autres translocations où sont en cause seulement les autosomes, les modifications trisomiques tertiaires de ces anomalies ef certaines translocations Robertsoniennes multiples. Dans tous ces cas la stérilité résulte d'un trouble de la spermatogenèse qui entraîne l'oligospermie ou l'azoospermie. Les études des translocations réciproques sont d'un intérêt particulier pour élucider les mécanismes impliqués, parce qu'elles offirent une gamme complète d'effets, allant de la production normale de spermatozoïdes à l'arrêt de la spermatogenèse au début de la méiose. Entre ces deux extrêmes, on peut reconnaître des types d'anomalies caractéristiques, mais en général l'arrêt de la spermatogenèse n'est pas tołal, mais plutôt graduel. Les anomalies de la spermatogenèse sont associables aux caractéristiques particulières des translocations elles-mêmes, particulièrement avec une tendance pour qu'un point de l'échange soit près ou même dans l'hétérochromatine centromérique et l'autre assez loin sur le chromosome en cause. Ceci conduit fréquemment à la formation de chromosomes marqueurs, longs et courts, et à la production de souris à trisomie tertiaire viables qui sont aussi en règle générale des mâles stériles.

\section{References}

BARANOV V. S., DYBAN A. P., 1968. Analysis of spermatogenic and embryogenic abnormalities in mice heterozygous for the chromosome translocation T6. Genetika, 4, 70-83.

BEECHEY C. V., 1973. X-Y chromosome dissociation and sterility in the mouse. Cytogenet. cell. Genet., $12,60-67$. 
Beechey C. V., SAVAge J. R. K., SeARle A. G., WIgGlesWORTH D. J., 1976. Private communication. Mouse News Letfer, 54, 38-39.

BEECHEY C. V., SEARLE A. G., 1975. Crosses between two 2 : 4 translocations (Private communication). Mouse News Letter, 53, 30.

CACHEIRO N. L. A., RUSSELL L. B., SWARTOUT M. S., 1974. Translocations, the predominant cause of total sterility in sons of mice treated with mutagens. Genetics, 76, 73-91.

CARTER T. C., LYON M. F., PHILLIPS R. J. S., 1956. Further genetic studies of eleven translocations in the mouse. J. Genet., 54, 462-474.

CATTANACH B. M., 1961. XXY mice. Genet. Res., Camb., 2, 156-158.

CATTANACH B. M., POLLARD C. E., 1969. An XYY sex-chromosome constitution in the mouse. Cytogenetics, 8, 80-86.

CHANDLEY, A. C., 1975. Human meiotic studies, 31-82. In EMERY A. E. H., Modern trends in human genetics, 2, Butterworths, London and Boston.

CHANDLEY, A. C., MACLEAN N., EDMOND P., FLETCHER J., WATSON G. S., 1976. Cytogenefics and infertility in man. II. Testicular histology and meiosis. Ann. hum. Genet. Lond., 40, 165-176.

DEV V. G., MILLER D. A., CHAREN J., MILLER O. J., 1974. Translocation of centromeric heterochromatin in the $T(10,13) 199 \mathrm{H}$ stock of Mus musculus and localization of chromosome breakpoints. Cytogenet. cell. Genet., 13, 256-267.

DORING L., WINKING H., GROPP A., 1975. Male sterility of double metacentric heterozygotes (Personal communication). Mouse News Letter, 52, 42.

EICHER E. M., 1970. X-autosome translocations in the mouse : total inactivation versus partial inactivation of the $X$ chromosome. Adv. Genet., 15, 175-259.

EICHER E. M., WASHBURN L., 1977. Private communications. Mouse News Letfer, 56, 43.

EVANS E. P., 1976. Male sterility and double heterozygosity for Robertsonian translocations in mouse, 75-81. In PEARSON P. L., LEWIS K. R., Chromosomes today, vol. 5, John Wiley and Sons, New York.

EVANS E. P., BEECHEY C. V., BURTENSHAW M. P., 1978. Meiosis and fertility in XYY mice. Cytogenet. cell. Genet. (in press).

EVANS E. P., BEECHEY C. V., SEARLE A. G., 1977. Private communication. Mouse News Letter, 57, 17.

EVANS E. P., BRECKON G., FORD C. E., 1964. An air-drying method for meiotic preparations from mammalian testes. Cytogenetics, 3, 289-294.

FORD C. E., EVANS E. P., BURTENSHAW M. D., CLEGG H. M., TUFFERY M., BARNES R. D., 1975. A functional \& sex-reversed » oocyte in the mouse. Proc. roy. Soc., Lond., 190, 187-197.

FORD C. E., SEARLE A. G., EVANS E. P., WEST B. J., 1969. Differential transmission of translocations induced in spermatogonia of mice by irradiation Cytogenetics, 8, 447-470.

FOREJT J., 1974. Non-random association between a specific autosome and the $X$ chromosome in meiosis of the male mouse : possible consequences of the homologous centromere's separation. Cytogenet. cell. Genet., 13, 369-383.

FOREJT J., 1977. Meiosis in sterile translocation carriers (Private communication). Mouse News Letter, 57, 36.

GROPP A., KOLBUS V., 1974. Exencephaly in the syndrome of trisomy no 12 of the foetal mouse. Noture, 249, 145-147.

LÉONARD A., DEKNUDT G., 1969. Cytological study of a translocation between the X-chromosome and an autosome in the mouse. Experientia, 25, 876-877.

LYON M. F., MEREDITH R., 1966. Autosomal translocations carrying male sterility and viable aneuploidy in the mouse. Cytogenetics, 5, 335-354.

LYON M. F., SEARLE A. G., FORD C. E., OHNO S., 1964. A mouse translocation suppressing sexlinked variegation. Cytogenetics, 3, 306-323.

MOSES M. J., RUSSELL L. B., CACHEIRO N. L. A., 1977. Mouse chromosome translocations : visualization and analysis by electron microscopy of the synaptonemal complex. Science, 196, 892-894.

NESBITT M. N., FRANCKE U., 1973. A system of nomenclature for band patterns of mouse chromosomes. Chromosoma (Berl.), 41, 145-158.

PEARSON P. L., ELLIS J. D., EVANS H. J., 1970. A gross reduction in chiasma formation during meiotic prophase and a defective DNA repair mechanism associated with a cause of human infertility. Cytogenefics, 9, 460-467. 
PURNELL D., 1973. Spontaneous univalence at male meiosis in the mouse. Cytogenet. cell. Genet., 12, 327-335.

RATHENBURG R., MULLER D., 1973. $X$ and $Y$ chromosame pairing and disjunction in a male mouse with an $X Y Y$ sex-chromosome constitution. Cylogenet. cell. Genet., 12, 81-144.

RUSSELL L. B., MONTGOMERY C. S., 1969. Comparative studies on X-autosome translocations in the mouse. I. Origin, viability, fertility and weight of five $T(X ; 1)$ 's. Genetics, 63, 103-120.

SEARLE A. G., 1974. Nature and consequences of induced chromosome damage in mammals. Genefics, 78, 173-186.

SEARLE A. G., BEECHEY C. V., 1974. Cytogenetics effects of $X$-rays and fission neutrons in female mice. Mulation Res., 24, 171-186.

SEARLe A. G., FORD C. E., eVANS E. P., BeEChey C. V., BURTENSHAW M. D., CLEGg H. M., 1974. The induction of translocations in mouse spermatozoa. I. Kinetics of dose response with acute X-irradiation. Mutation Res., 22, 157-174.

SLIZYNSKI B. M., 1964. Cytology of the XXY mouse. Genet. Res., 5, 328-329.

WINKING H., GROPP A., 1977. Male sterility in double metacentric heterozygotes with monobrachial homology (Personal communication). Mouse News Letter, 56, 47. 